\title{
Transformasi Novel Arini Karya Mira W Ke Dalam Film Arini Karya Sutradara Ismail Basbeth
}

\author{
Erlinawati $^{1)}$, Nensilianti ${ }^{2)}$, Hajrah $^{3)}$ \\ erlinawatii27@gmail.com ${ }^{1)}$, nensilianti@unm.ac.id ${ }^{2)}$, hajrah@unm.ac.id ${ }^{3)}$ \\ Universitas Negeri Makassar, Jalan Daeng Tata, Makassar
}

\begin{abstract}
Abstrak. Penelitian ini bertujuan untuk mendeskripsikan bentuk-bentuk penciutan, penambahan, dan perubahan variasi yang muncul dari transformasi novel ke film Arini Masih Ada Kereta yang akan Lewat berdasarkan kajian ekranisasi. Penelitian ini merupakan penelitian kualitatif yang bersifat deskriptif. Sumber data penelitian ini adalah novel Arini Masih Ada Kereta yang akan Lewat karya Mira W dan film Arini Masih Ada Kereta yang akan Lewat karya sutradara Ismail Basbeth. Hasil penelitian ini menunjukkan bahwa karya sastra mampu melakukan transformasi ke media baru yakni media film. Pengumpulan data dilakukan dengan teknik baca, teknik catat dan teknik dokumentasi. Data pada penelitian ini dianalisis, menbaca, mengidentifikasi, membandingkan unsur intrinsik yang ada pada novel dan film. Transformasi adalah perubahan, yaitu perubahan terhadap suatu hal atau keadaan. Jika suatu hal atau keadaan yang berubah itu adalah budaya, budaya itulah yang mengalami perubahan.
\end{abstract}

Kata Kunci: novel, film, ekranisasi, transformasi

\section{Pendahuluan}

Dalam dunia kesenian sering di jumpai berbagai bentuk perubahan dari satu bentuk karya seni ke jenis karya seni lainnya yang biasa disebut dengan istilah transformasi. Misalnya, dari puisi ke musik, seperti puisi Taufik Ismail yang dilagukan oleh grup musik Bimbo, dari cerpen ke film seperti cerpen Tentang Dia yang kemudian diubah menjadi film Tentang Dia, dari novel ke drama seperti Bunga Raos Dari Cikembang karya Kwee Tek Hoy (Oktafiyani, dkk, 2017). Kegiatan tersebut dinamakan dengan istilah transformasi. Damono mempunyai istilah lain untuk mengubah satu jenis kesenian menjadi kesenian lain dengan istilah alih wahana (Damono, 2012).Alih wahana merupakan salah satu bentuk usaha dalam pengembangan sastra sebagaimana dikemukakan dalam peraturan pemerintah nomor 57 tahun 2014 tentang pengembangan, pembinaan, perlindungan bahasa dan sastra, serta peningkatan fungsi bahasa Indonesia (Meilinda 2018).

Adaptasi dari satu bentuk karya seni ke bentuk karya seni lain sudah sering dilakukan oleh para seniman dalam sejarah perfilman dunia, khususnya Hollywood, sembilan puluh persen karya skenario film dan televisi asal dari adaptasi novel, misalnya film Harry Potter yang merupakan adaptasi dari novel karya J.K.Rowling yang berjudul Harry Potter, film TheLord of the Ringsdiadaptasi dari novel The Lord of the Rings karya Tolkien tahun 1954 (Karkono, 2009). Bermacam-macam alasan mendasari proses transformasi dari novel ke film. Alasan-alasan tersebut antara lain karena sebuah novel sudah terkenal sehingga tidak asing lagi bagi masyarakat, ketidakasingan tersebut mendukung aspek komersil. Alasan terakhir adalah karena ide cerita novel dianggap bagus oleh masyarakat dan penulis skenario film(Adi, 2016).

Pengaruh ekranisasi novel menjadi film di era millenial seperti sekarang ini memberikan dampak positi dan negatif.Dampak positifnya yaitu menambah dan meningkatkan kreativitas seseorang dalam mengolah isi novel menjadi skenario yang layak untuk dijadikan film. Sedangkan negatifnya yaitu dapat mengurangi minat baca seseorang karena mereka menganggap ada yang lebih mudah untuk mengetahui isi dari novel tersebut tanpa harus membaca yaitu dengan menonton film tersebut yang dapat disaksikan secara visual dan dapat di akses lebih 
mudah melalui telepon genggam, televisi maupun bioskop.

Eneste (1991) juga Mengatakan dari novel ke layar lebar atau film mau tidak mau akan menimbulkan proses penciutan atau pengurangan, penambahan dan perubahan bervariasi. Pada proses penciutan akan terjadi pemotongan peristiwa ada juga beberapa tokoh dan latar yang tidak ditampilkan karena dianggap tidak penting untuk ditampilkan dalam film. Begitu juga dengan penambahan akan terjadi penambhan peristiwa, tokoh maupun latar karena dianggap dibutuhkan untuk menunjang hasil yang maksimal dalam film. Demikian pula dengan perubahan bervariasi ini dilakukan agar beberapa adegan yang terdapat pada novel yang dianggap tidak layak ditampilkan sehingga menjadi layak untuk ditampilkan dalam film untuk disajikan kepada masyarakat.

Masalah yang diangkat dalam penelitian ini adalah: (1) bentuk transformasi penciutan padanovel Arini Masih Ada Kereta yang Akan Lewat karya Mira W. ke dalam film Arini Masih Ada Kereta yang Akan Lewat sutradara Ismail Basbeth (2) Bagaimana bentuk transformasi penambahan padanovel Arini Masih Ada Kereta yang Akan Lewat karya Mira W. ke dalam film Arini Masih Ada Kereta yang Akan Lewat sutradara Ismail Basbeth (3) Bagaimana bentuk transformasi perubahan variasi padanovel Arini Masih Ada Kereta yang Akan Lewat karya Mira W. ke dalam film Arini Masih Ada Kereta yang Akan Lewat sutradara Ismail Basbeth.

Secara umum tujuan penelitian ini mendeskripsikan bentuk penciutan, penambahan, dan perubahan variasi tokoh, alur dan latar dalam novel Arini Masih Ada Kereta yang Akan Lewat Karya Mira W ke dalam film Arini Masih Ada Kerea yang Akan Lewat karya Sutradara Ismail Basbeth dengan menggunakan pendekatan Ekranisasi Pamusuk Eneste 1991. Secara spesifik, penelitian ini mendeskripsikan (1) bentuk transformasi penciutan padanovel Arini Masih Ada Kereta yang Akan Lewat karya Mira W. ke dalam film Arini Masih Ada Kereta yang Akan Lewat sutradara Ismail Basbeth (2) Bagaimana bentuk transformasi penambahan padanovel Arini Masih Ada Kereta yang Akan Lewat karya Mira W. ke dalam film Arini Masih Ada Kereta yang Akan Lewat sutradara Ismail Basbeth (3) Bagaimana bentuk transformasi perubahan variasi padanovel Arini Masih Ada Kereta yang Akan Lewat karya Mira W. ke dalam film Arini Masih Ada Kereta yang Akan Lewat sutradara Ismail Basbeth.

\section{Metode}

Sesuai dengan rumusan masalah dan tujuan penelitian, metode yang digunakan dalam penelitian ini adalah metode kualitatif yang bersifat Deskriptif. Menurut Moleong (2014) penelitian kualitatif adalah penelitian yang bermaksud untuk memahami fenomena tentang yang dialami oleh subjek penelitian misalnya pelaku, persepsi, motivasi, tindakan dan lain-lain secara holistik dan dengan cara deskripsi dalam bentuk kata-kata dan bahasa, pada suatu konteks khusus yang alamiah dan dengan memanfaatkan berbagai metode alamiah.

\section{Hasil dan Pembahasan}

Berdasarkan hasil analisis data yang terdiri dari tiga, yaitu: 1) Penciutan yang muncul dari transformasi novel ke film Arini Masih Ada Kereta yang Akan Lewat. 2) Penambahan yang muncul dari transformasi novel ke film Arini Masih Ada Kereta yang Akan Lewat. 3) Perubahan bervariasi yang mucul dari transformasi novel ke film Arini Masih Ada Kereta yang Akan Lewat. Penciutan, penambahan, dan perubahan variasi yang muncul dari novel ke film Arini Masih Ada Kereta yang Akan Lewat ditemukan tokoh, alur, dan latar. 
1. Bentuk Penciutan Novel Arini Masih Ada Kereta yang Akan Lewat karya Mira W. dengan film Arini Masih Ada Kereta yang Akan Lewat karya sutradara Ismail Basbeth

Novel dan film adalah karya sastra, keduanya bisa berdiri sendiri dengan kekurangan dan kelebihan masing-masing. Oleh karena itu, sulit untuk memakasakan hasil pelayar putihan jika indikasinya adalah menemukan kesamaan hingga seratus persen. Novel adalah bahasa tulisan yang daya jangkaunya sangat luas, tidak ada batasan sebab yang bermain adalah imajinasi penulis. Sementara itu, dalam proses pembuatan film sutradara akan mewujudkan imajinasi penulis karena itu tak jarang kendala ditemukan. Kendala yang dimaksud bisa berupa durasi, pengadaan alat, pemilihan tokoh dan latar, hingga pada permasalahn biaya. Sehingga yang terjadi selanjutnya adalah terdapat bagian-bagian pada novel yang tidak dihadirkan hanya saja tidak sesuai dengan ekpektasi pembaca.

\section{a. Penciutan Tokoh}

Penciutan tokoh terjadi pada sosok Marga yakni anak dari Ira dan Hadi bisa jadi juga Marga adalah anak Ira bersama Helmi, karena pada saat Ira dan Hadi menjadi suami istri Ira berselingkuh dengan Helmi. Hal tersebut dapat diamati dalam kutipan novel berikut:

Anaknya yang ketiga lahir pada saat mereka sedang hangat-hangatnya bercinta. Ira sendiri tidak tahu siapa ayahnya. Tetapi hemi selalu menganggap Marga anaknya.

Di mata semua orang, Marga anak Hadi.Bahkan dikepala Hadi sendiri, marga anak kesayangannya. Bungsu. satunya perempuan (Mira, 218:26)

Pada kutipan di atas dapat dilihat bahwa sosok Marga yaitu anak dari Ira dan Hadi. Ira merupakan sahabat Arini yang berselingkuh dengan Helmi suaminya. Dari perselingkuhan mereka lahirlah seorang anak bernama Marga. Ira sempat kebingungan apakah Marga anaknya bersama Hadi atau bersama Helmi. Pada film sosok marga tidak akan kita temukan dalam film karena kehadirannya tidak memiliki pengaruh sama sekali dalam film, pada novel pun hanya disebutkan namanya dan keberadaanya tidak begitu jelas penceritaannya. Oleh sebab itu sosok Marga ditiadakan oleh sutradara karena Marga hanya sebagai tokoh tambahan pelengkap cerita tokoh utama dalam novel sehingga tidak akan mempengaruhi jalannya cerita jika tokoh tersebut tidak dimasukkan dalam film dan adanya keterbatasan durasi juga menjadi salah satu faktornya.

\section{b. Penciutan Alur}

Penciutan alur pertama kali terjadi saat Nick mencium Arini pertama kali di pertemuan pertama mereka didalam kabin kereta cepat yang ada di Eropa. Adegan tersebut tidak dimunculkan dalam film. Hal tersebut dibuktikan pada kutipan berikut:

"Terima kasih" kata-katanya belum selesai ketika pintu gerbong sebelah terbuka dari dalam. Secepat kilat anak muda itu menarik tubuh Arini kedalam pelukannya. Mendekapnya. Dan mencium bibirnya mencegah pekikan kaget yang meluncur dari bibir wanita itu (Mira, 2018: 11)

Pada kutipan diatas dapat dilihat bahwa saat itu Nick memeluk dan mencium Arini. Hal itu dihilangkan karena dianggap terlalu vulgar untuk dimunculkan diawal bagian pada film sehingga terjadi penciutan alur tersebut mengingat konsistensi penonton film tersebut bukan 
hanya dari kalangan dewasa melainkan semua kalangan penonton dapat menyaksikan film tersebut.

\section{c. Penciutan latar}

Latar tempat terdapat pada tokoh atau pelaku yang mengalami kejadian atau peristiwa di dalam cerita. Penciutan latar tempat terjadi pada kamar sewaan Arini. Penggambaran tentang kamar sewaan Arini ketika Arini baru diantarkan pulang oleh Helmi setelah mereka bertemu untuk pertama kalinya. Hal tersebut dapat diamati pada kutipan berikut;

"Rasanya percuma saja Ir," keluhnya ketika mereka sudah berada di dalam kamar sewaannya lagi setelah di antarkan pulang oleh Helmi. "Dia tdak berminat.

Arini meletakkan tas tangan yang dipinjamkan Ira dengan kasar di atas meja. Tas yang harganya puluh kali lipat gajinya sebulan. (Mira, 2018:15)

Dari kutipan tersebut dapat dilihat bahwa Arini dan Ira berada di dalam kamar sewaannya. Namun pada film tidak akan ditemukan sebuah kamar kos melainkan rumah Arini. Hal ini dilakukan oleh sutradara karena untuk mengurangi latar tempat yang digunakan sehingga kamar kos Arini digabung menajadi rumah yang dihuni bersama ibunya. Pada novel Arini tinggal beda kota dengan ibunya namun, pada film diceritakan mereka tinggal bersama karena sutradara juga melakukan perubahan dari segi alur cerita dengan menghilangkan latar kos Arini dan menggantinya dengan rumah yang ditinggali oleh Arini dan ibunya. Hal ini juga dapat mengurangi latar tempat yang harus digunakan dengan cara menghilangkan beberapa latar tempat yang dianggap tidak penting.

\section{Bentuk Penambahan Novel Arini Masih Ada Kereta yang Akan Lewat karya Mira W. dengan film Arini Masih Ada Kereta yang Akan Lewat karya sutradara Ismail Basbeth}

\section{a. Penambahan Tokoh}

Penambahan tokoh sangat mempengaruhi alur maupun jalan cerita karena itu tidak gampang menambahkan tokoh pada film jika sebelumnya tokoh yang dimaksud tidak terdapat pada novel. Sebagaimana film Arini, tidak terlihat penambahan tokoh yang signifikan. Hanya saja terdapat satu bagian tokoh yang ditambahkan yaitu kasir sebuah mini market. Kehadirannya dianggap perlu ditambhakan karena pada novel hanya diceritakan Arini yang keluar supermarket dengan membawa kantongan belanjaanya. Terdapat pada scene 12 durasi 20.11-20.27

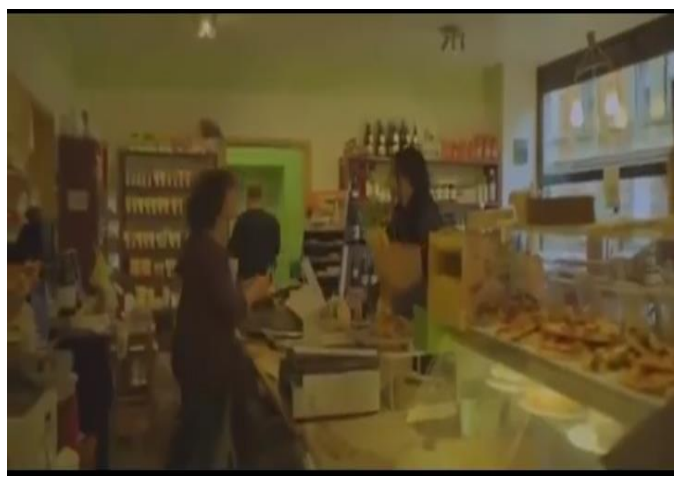

Gambar 1. Penambahan Tokoh 
Pada gambar tersebut dapat dilihat bahwa saat itu Arini sedang berbelanja disebuah mini market. Pada novel tidak diceritakan adanya seorang kasir atau siapa saja yang ada dalam mini market tersebut, namun dalam film sosok kasir ditambahnkan oleh sutradara agar film menjadi lebih jelas atau penggamabaran saat Arini berbelanja lebih mudah dimengerti karena setelah Arini mengambil barang di toko tersebut ia harus membayar belanjaanya sehingga dianggap perlu menambahkan sosok kasir dalam film.

\section{b. Penambahan Latar}

Penambahan Latar saat Arini dan Nick melakukan perjalanan ke Heidelberg. Disana mereka melihat pemandangan kota Heidelbergyang dibelah oleh sungai Neckar dari jembatan. Setelah mereka pulang diceritakan mereka saat sedang menunggu kereta. Arini dan Nick duduk di kursi stasiun. Di dalam novel hanya diceritakan perjalanan mereka sampai pulang tidak diceritakan ada adegan menunggu disebuah stasiun. Dibuktikan melalui scene 24 durasi 34.1834.42 .

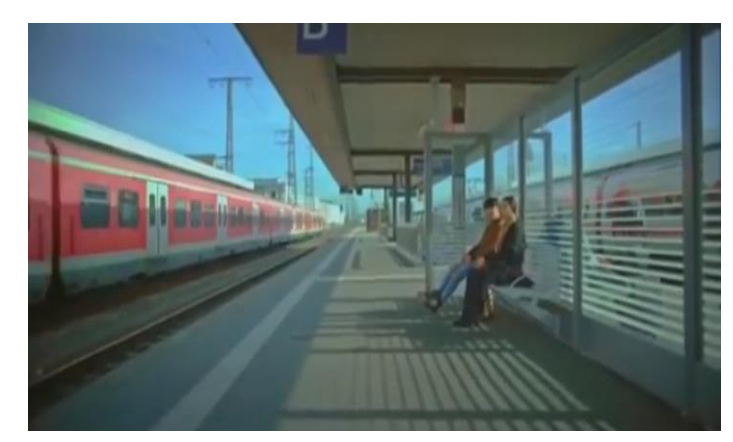

Gambar 2. Penambahan Latar

Pada gambar di atas dapat dilihat Arini dan Nick sedang berada disebuah stasiun kereta. Pada novel tidak diceritakan pada pertengahan jalan cerita mereka berada disebuah stasiun menunggu kereta yang akan mereka gunakan untuk pulang. Hal ini ditambahkan karena sutradara ingin memperjelas cerita yang ada pada judul cerita yakni Arini Masih Ada Kereta yang Akan Lewat. Maka dari itu diperlihatkan latar stasiun kereta pada awal, pertengahan dan akhir cerita. Pemfokusan cerita tidak hanya pada kisah percintaan Arini namun, sutradara ingin menggambarkan tentang bagaimana perjalan Arini dan Nick yang awal pertemuannya disebuah kabin kereta, selama mejalani hubungan dan di akhir cerita mereka dipertemukan kembali di stasiun kereta tersebut.

\section{c. Penambahan Alur}

Arini dan Nick saat melakukan perjalanan ke Heidelberg terdapat penambahan Alur yang mendukung jalannya cerita pada saat itu sehingga ceritanya saling berhubungan dan mudah dimengerti oleh penonton yaitu Arini dan Nick berbaring di atas rerumputan ditengah pepohonan saat mereka berlarian menuju jembatan sungai Neckar. Mereka kelelahan dan istirahat lalu berbaring memandangi langit terkadang mereka saling memandang. Dibuktikan melalui scene 17 durasi 26.40- 28.14. 


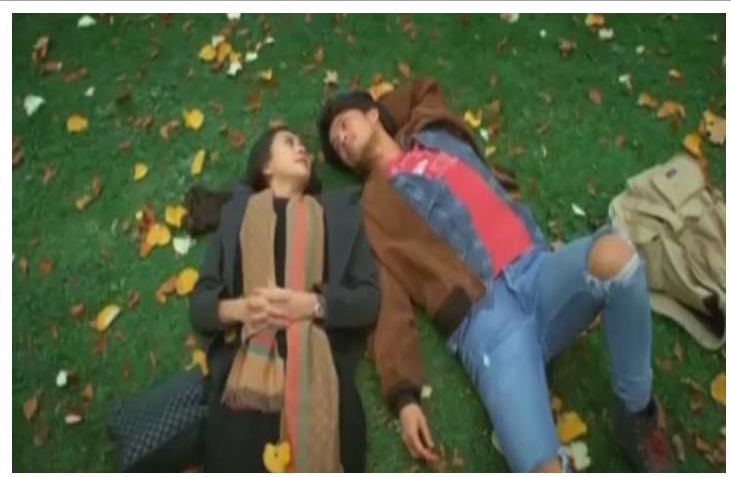

Gambar 3. Penambahan Alur

Penambahan alur ini dilakukan karena adanya perubahan variasi yang dilakukan pada latar tempat tersebut sehingga jalan ceritanya juga ikut berubah. Pada novel diceritakan Arini dan Nick mengelilingi bangunan tua yang ada di Stuttgart namun sutradara dan tim menganti lokasi ke Nuremberg karena masyarakat di lokasi tersebut melarang untuk melakukan pengambilan gambar Stuttgart sehingga terjadi perubahan lokasi menjadi Arini dan Nick berlari disebuah taman menuju sungai Neckar agar carita tidak membosankan sehingga ditambahkan alur cerita Arini dan Nick berbaring diatas rumput agar jalan cerita dapat saling terhubung dan kesan romantisnya dapat membuat penonton merasakannya ketika menonton film tersebut.

\section{Bentuk Perubahan Variasi Novel Arini Masih Ada Kereta yang Akan Lewat karya Mira W. dengan film Arini Masih Ada Kereta yang Akan Lewat karya sutradara Ismail Basbeth}

\section{a. Perubahan Variasi Tokoh}

Perubahan tokoh hanya satu dalam novel terjadi pada karakter Arman yang diceritakan dalam novel dia berusia lima tahun. Arini menelpon Ira untuk memberitahu bahwa dia akan segera melahirkan. Namun bukan Ira yang mengangkat melainkan Arman anaknya yang berusia lima tahun. Hal tersebut dapat dilihat pada kutipan berikut.

"Celakanya bukan Ira yang menerima telepon itu. Tetapi Arman, anaknya yang kedua. Yang baru beruumur lima tahun." (Mira, 2018: 111)

Pada kutipan tersebut dapat diketahui bahwan Arman sebagai anak kecil yang baru berusia lima tahun. Berbeda dengan yang dihadirkan dalam film. Digambarkan Arman sudah kisaran remaja atau berumur sekitar lima belas tahun. Di buktikan melalui scene 22 durasi 33.31-33.59.

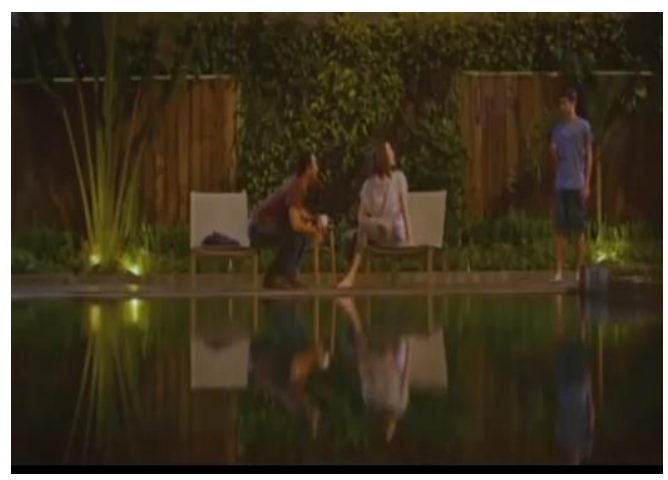

Gambar 4. Perubahan Variasi Tokoh 
Pada gambar tersebut dapat dilihat bahwa sosok Arman terlihat sudah remaja namun pada novel Arman diceritakan sebagai seorang anak kecil yang berusia lima tahun. Perubahan ini dilakukan karena jika sutradara tetap menggunakan anak yang berusia lima tahun maka akan sulit melakukan pengambilan gambar film tersebut dan sulit melakukan komunikasi dengan anak berusia lima tahun sehingga yang dipakai dalam film adalah remaja yang sudah mampu berkomunikasi dengan baik.

\section{a. Perubahan Variasi Latar}

Perubahan variasi terjadi pada novel dan film yang berbeda medium. Dari perbedaan tersebut terjadi perubahan latar. Perubahan latar terjadi pada saat Arini dan Nick ingin pulang ke apartemennya di novel di ceritakaan saat mereka pulang Arini dan Nick menaiki trem yang berada di depan toko tersebut. Dapat dilihat pada kutipan berikut.

\section{"Kita naik trem saja ya? Dari tadi tidak ada taksi."}

Tanpa menunggu jawaban, Nick langsung melompat kedalam trem.

"Lekas naik!" teriaknya dari ambang pintu trem.Jangan takut saya sudah punya karcis.” (Mira, 2018: 69)

Berdasarkan kutipan tersebut dapat diketahui saat itu mereka sedang naik trem. Namun saat medianya berpindah ke film, Nick dan Arini hanya berjalan kaki pulang sampai ke apartemennya. Di buktikan melalui scene 13 durasi 21.26-24.43.

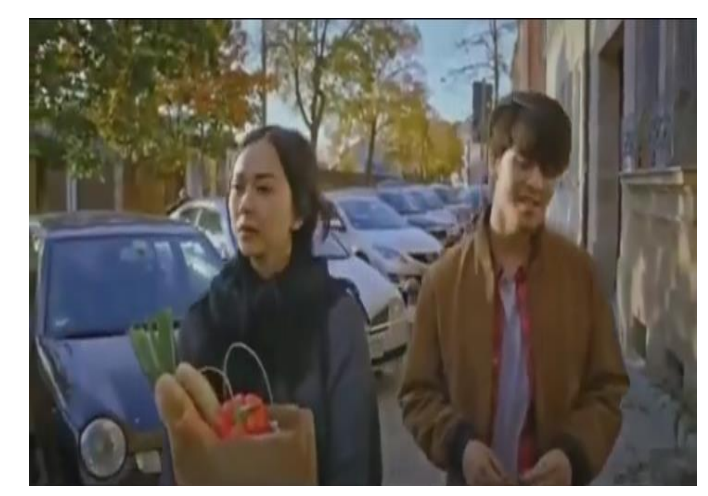

Gambar 5. Perubahan Variasi Latar

Pada gambar di atas dapat dilihat bahwa saat itu Arini dan Nick sedang berjalan kaki saat akan pulang menuju apartemennya namun pada novel diceritakan mereka pulang dengan menaiki sebuah trem. Perubahan variasi ini terjadi karena adanya keterbatasan biaya dan sutradara juga mengganti lokasi apartemen Arini tidak jauh dari mini market tempat ia berbelanja agar lebih mudah untuk dijangkau walaupun hanya dengan berjalan kaki saja dan lebih mempermudah kru film dalam pengambilan gambarnya Sehingga sutradara mengubah bentuk penceritaannya. Namun, apa yang ingin disampaikan dari novel ke film tetap sama.

\section{b. Perubahan Variasi Alur}

Perubahan Alur terjadi dalm novel saat Nick kerumah Arini ingin mengembalikan HP miliknya. Saat Nick menekan tombol bel Arini merasa terkejut karena baru pertama kalinya dia mendapat tamu malam-malam. Kemudian Arini menghampiri monitor interkom dan menekan tombolnya dia melihat wajah Nick. Hal tersebut dapat dilihat pada kutipan berikut: 
"Arini sedang menyiapkan makan malamnya ketika bel pintu berdering sekejap dia merasa takut. Siapa yang malam-malam begini mengunjunginya?

Dia tidak punya teman kencan.Memang salahnya sendiri.Dia selalu menolak ajakan mereka.Dia tidak percaya lagi pada laki-laki.

Dia menghampiri monitor interkom. Dan menekan tombolnya.

"Nick!" sergah Arini saat melihat anak muda itu dilayar monitor. "Ada Apa?". "(Mira, 2018: 33)

Pada kutipan tersebut dapat dilihat saat itu Nick datang ke Apartemen Arini untuk mengembalikan Hpnya. Namun berbeda pada film Nick memberitahu Arini kalau HP miliknya ada padanya melalui telepon. Nick menelpon Arini melalui telepon rumah karena hanya nomor tersebut yang dapat dihubungi mengingat saat itu HP Arini ada pada Nick. Mereka berbicara melalui telpon tersebut bukan melalui monitor interkom. Dibuktikan melalui scene 7 durasi 09.35-11.40

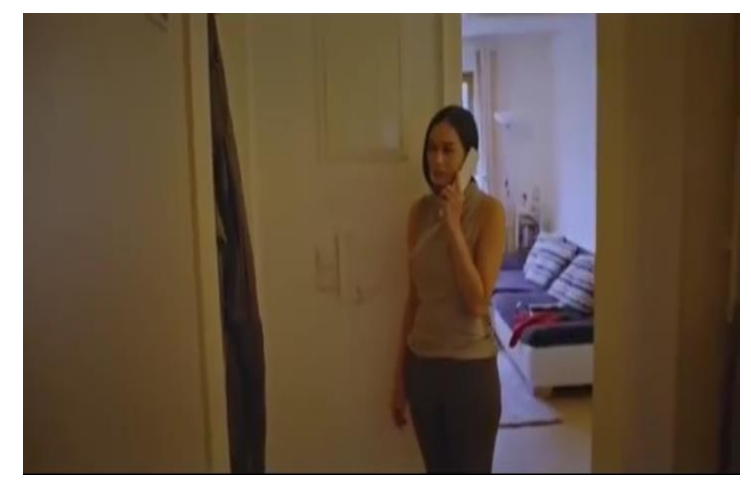

Gambar 6. Perubahan Variasi Alur

Pada gambar tersebut dapat dilihat Arini sedang menelpon dengan Nick pada novel diceritakan Nick datang langsung ke apartemen Arini sedangkan pada film Nick terlebih dahulu menghubungi Arini melalui telepon rumah yang terdapat pada HP Arini yang saat itu masih ada pada Nick, alur cerita tersebut diubah karena apartemen yang digunakan Arini tidak memiliki intercom dan untuk mengurangi biaya kru film menyewa apartemen yang sedikit lebih murah sehingga diubah menjadi Nick menghubunginya melalui telepon yang ada diaparteman Arini.

Meskipun terjadi variasi-variasi tertentu antara novel dan film, pada hakikatnya tema/amanat dari novel Arini Masih Ada Kereta yang Akan Lewat masih terungkap dalam film. Novel ini hendak mengamanatkan: Jagalah kepercayaan seseorang dan janganlah menjadikan sebuah pernikahan itu seperti mainan yang jika bosan cari yang lain atau beli yang baru.

Berdasarkan novel yang diadaptasi terjadi perubahan disebabkan oleh perbedaan medium yang digunakan antara novel dan film dalam penyampaian cerita dan pesan masing-masing, serta pemahaman teks karya sastra yang berbeda oleh setiap individu. Meskupin demikian pesan yang ingin disampaikan novel dan film bisa diterima oleh berbagai kalangan masyarakat dengan tidak meninggalkan pesan yang dimaksud oleh karya sastra.

\section{Simpulan}

Berdasarkan hasil temuan bentuk penciutan, penambahan, dan perubahan variasi dari segi tokoh, latar dan alur yakni sebagai berikut. Pertama dari segi pernciutan tokoh terjadi pada tokoh marga, penciutan latar terjadi pada kamar sewaan Arini, dan penciutan Alur yakni pada 
adegan saat Nick mencium Arini di dalam kabin kereta. Penciutan ini terjadi karena adanya beberapa hal yang dianggap tidak perlu untuk dimasukkan dalam film mengingat konsistensi durasi waktu yang terbatas. Kedua dari segi penambahan tokoh terjadi pada tokoh kasir, penambahan latar terjadi pada stasiun kereta dipertengahan cerita, dan penambahan alur saat Nick dan Arini berbaring di atas rumput setelah berjalan mengelilingi kota Stuttgard. Penambahan ini terjadi karena dianggap perlu agar jalan cerita bisa saling terhubung dan mudah dipahami oleh penonton. Ketiga dari segi perubahan variasi tokoh terjadi pada tokoh Arman, perubahan variasi latar terjadi saat Arini pulang dari mini market, dan perubahan alur terjadi pada saat Nick ingin mengembalikan Hp milik Arini. Perubahan variasi ini perlu dilakukan agar penggambaran cerita dari novel lebih mudah untuk dipahami. Berdasarkan novel yang diadaptasi terjadi perubahan disebabkan oleh perbedaan medium yang digunakan antara novel dan film dalam penyampaian cerita dan pesan masing-masing, serta pemahaman teks karya sastra yang berbeda oleh setiap individu. Meskupin demikian pesan yang ingin disampaikan novel dan film bisa diterima oleh berbagai kalangan masyarakat dengan tidak meninggalkan pesan yang dimaksud oleh karya sastra.

\section{Daftar Pustaka}

Adi, I.R. (2016). Fiksi populer teori dan metode kajian. Pustaka Pelajar. Yogyakarta. Damono, SapardiDjoko. 2012. AlihWahana. Jakarta: Editum

Eneste, Pamusuk. 1991. Novel dan film. Nusa Indah. Flores

J.Moleong, Lexy. 2014. Metode Penelitian Kualitatif, Edisi Revisi. PT Remaja Rosdakarya. Bandung.

Karkono. 2009. Perbedaan makna novel dan film Ayat Ayat Cinta: Kajian Ekranisasi. ATAVISMF, Vol. 12 No. 2, 167-180. DOI: 10.24257/atavisme.v12i2.168. 167-180

Meilinda, Resky. 2018. Alih Wahana Struktur Faktual Novel Surga Yang Tak Dirindukan 2 Karya Asma Nadia ke Film Surga Yang Tak Dirindukan 2 Karya Hanung Bramantyo. SKRIPSI. FBS. UNM.

Mira W. (2018). Arini masih ada kereta yang akan lewat. PT Gramedia Pustaka Utama. Jakarta Oktayani, A, dkk.2017. Transformasi Makna Simbolik Mirharb pada Novel ke Film dalam Mirhab Karya Habiburrahman E Shirazy. Jurnal Sastra Indonesia.Vol. 6 No. 3. 